\title{
Relative Susceptibility Among Alternative Host Species Prevalent in the Great Plains to Wheat streak mosaic virus
}

D. Ito and Z. Miller, Plant Sciences and Plant Pathology Department, F. Menalled, Land Resources and Environmental Sciences Department, and M. Moffet and M. Burrows, Plant Sciences and Plant Pathology Department, Montana State University, Bozeman 59717 \begin{abstract}
Plains to Wheat streak mosaic virus. Plant Dis. 96:1185-1192.
Wild grasses, crops, and grassy weeds are known to host Wheat streak mosaic virus (WSMV) and its vector, the wheat curl mite (WCM). Their relative importance as a source of WSMV was evaluated. A survey of small-grain fields throughout Montana was conducted between 2008 and 2009. Cheatgrass was the most prevalent grassy weed and the most frequent viral host, with $6 \%$ infection by WSMV in $2008(n=$ $125)$ and $15 \%$ in $2009(n=358)$. By mechanically inoculating plants with WSMV in the greenhouse, the highest susceptibility was found in rye brome $(52.1 \%)$, jointed goatgrass $(80.9 \%)$, and wild oat $(53.9 \%)$. Quackgrass, not previously reported as a host, was susceptible to
\end{abstract}

Abstract

Ito, D., Miller, Z., Menalled, F., Moffet, M., and Burrows, M. 2012. Relative susceptibility among alternative host species prevalent in the Great

WSMV (12.7\%). Mite transmission efficiency from susceptible grass species was lower than from wheat, and grass species must be a host for both WSMV and the WCM to serve as a virus source. WCM transmission was more efficient than mechanical transmission. Overall, results indicate that grass species can serve as a viral reservoir, regional variation in a weed species' susceptibility to WSMV cannot explain geographic variation in epidemic intensity, and crop species and closely related weeds (e.g., jointed goatgrass) remain the best reservoirs for both WSMV and the WCM.
Control of Wheat streak mosaic virus (WSMV) relies on cultural practices to control the vector, the wheat curl mite (WCM; Aceria tosichella Keifer), and, to a lesser extent, on the use of resistant or tolerant crop cultivars $(9,18,43,53)$. Both the virus and vector are dependent on the "green bridge", or green host plant material between the harvesting of one crop and the planting of the next crop (49). Although volunteer crops are the principal reservoir of both WSMV and WCMs, various grassy weed species have been shown to be alternate hosts for the virus and mite (6). The need to better understand the role of grassy weed species in disease cycles of wheat viruses was heightened by the discovery of two new viruses, Wheat mosaic virus (WMoV, formerly named High Plains virus) and Triticum mosaic virus (TriMV). Both of these viruses have disease cycles similar to WSMV, are transmitted by the WCM, and are able to infect grassy weeds (38-41). Co-infection of a single plant with multiple wheat viruses has been reported and is known to enhance symptom severity and yield loss $(26,50)$. Pathogen prevalence, severity, and the frequency of epidemics differ across the Great Plains $(10,11)$. One explanation for this observed difference could be that weed species differ in their ability to serve as hosts to virus or the WCM across a wide geographic region.

Both vector and virus are restricted to a diverse set of grass species, including crops as well as grassy native and weedy species. WSMV infections have been reported in 41 species of annual grasses $(12-15,44,45,49)$. Crops, including barley (Hordeum vulgare L.), broomcorn millet (Panicum miliaceum L.), corn (Zea mays L.), foxtail millet (Setaria italica (L.) P. Beauv.), pearl millet (Pennisetum glaucum L.), cereal rye (Secale cereale L.), sorgum (Sorghum bicolor (L.) Moensch), common oat (Avena sativa L.), triticale (Triticale hexaploide Lart.), and wheat, are susceptible to

Corresponding author: M. Burrows, E-mail: mburrows@ montana.edu

GenBank accession number: HM535796.

Accepted for publication 9 March 2012.

http://dx.doi.org/10.1094/PDIS-09-11-0746-RE

(C) 2012 The American Phytopathological Society
WSMV $(37,41,44)$. WCMs have been found on 54 grass species, including six crops and 35 wild grass species $(8,12,14,49)$. Grassy weeds identified as important in the green bridge in the Great Plains region include rye brome (Bromus secalinus L.), cheatgrass (syn. downy brome; B. tectorum L.), green bristlegrass (syn. green foxtail; Setaria viridis (L.) Beauv.), jointed goatgrass (Aegilops cylindrica Host.), and wild oat (Avena fatua L.) $(8,49,53)$.

Although there is information about the susceptibility of grass species to WSMV and the WCM, regional investigations are needed because genetic composition of host species, vector, and virus vary spatially and this variation can, in turn, affect plant infection rates $(12,30,38,51)$. Indeed, evaluations of disease and mite susceptibility differ across studies and within species $(8,13,14,19,32,36,44-46)$. For example, Sill and Agusiobo (44) described mechanical inoculation of various millet species from around the world. Foxtail millet (S. italica L.) varied from 7 to $100 \%$ infection and barnyardgrass (Echinochloa crus-galli (L.) Beauv.) and proso millet (Panicum miliaceum L.) from immune to $100 \%$ (44). Wheat varieties also vary in susceptibility $(7,24,43)$.

This study focuses on alternative hosts of WSMV to evaluate the relative quality of grassy weed species as hosts of WSMV and the WCM. First, we conducted a field survey to identify grassy weeds in Montana that can act as host of WSMV. We also evaluated whether susceptibility to WSMV differed among grassy weed genotypes collected from six Great Plains states. Finally, we assessed the capacity of WSMV-susceptible weeds to serve as sources for transmission by WCMs to wheat and the efficiency of mite transmission of WSMV to several hosts.

\section{Materials and Methods}

Virus isolate identification and maintenance. Symptomatic winter wheat plants were collected in 2007 from Conrad, MT. Plants were tested with enzyme-linked immunosorbent assay (ELISA) as described below. An isolate obtained from these plants (designated Conrad-I) was mechanically transferred to and maintained in susceptible spring wheat 'Choteau' in the greenhouse. The greenhouse was maintained with a photoperiod of 16 and $8 \mathrm{~h}$ (day and night, respectively) and temperatures of $24 \pm 4^{\circ} \mathrm{C}$ (day) and $18 \pm 4^{\circ} \mathrm{C}$ (night) in the Plant Growth Center, Montana State University, Bozeman. The planting media used was a 1:1:1:3 mix- 
ture by volume of steam-pasteurized mineral soil, Canadian sphagnum peat moss (Aquagro 2000G; Aquatrols, Paulsboro, NJ), washed concrete sand, and Sunshine Mix number 2 Basic (Sun Gro Horticulture, Vancouver, BC, Canada).

For mechanical inoculation, symptomatic leaves were ground in a plastic extraction bag (Agdia, Inc., Elkhart, IN) at a 1:10 (weight $[\mathrm{g}] /$ volume $[\mathrm{ml}]$ ) ratio with phosphate-buffered saline (PBS; 136.9 $\mathrm{mM} \mathrm{NaCl}, 8.1 \mathrm{mM} \mathrm{Na}_{2} \mathrm{HPO}_{4}, 1.5 \mathrm{mM}$ of $\mathrm{KH}_{2} \mathrm{PO}_{4}$, and $2.9 \mathrm{mM}$ $\mathrm{KCl}, \mathrm{pH}$ 7.2). Approximately $1 \%$ (wt/vol) of Carborundum (320 grit) was added as an abrasive. Wheat leaves were gently rubbed two or three times between gloved fingers dipped into the inoculum.

WSMV strain Conrad-I coat protein was amplified from cDNA using forward primer H8369 and reverse primer C8908 (31) using published protocols. The sequence was deposited in GenBank as accession HM535796. The HM535796 accession was compared with other GenBank accessions using BLASTn 2.2.26 (1) and numerous WSMV accessions had $99 \%$ sequence identity, including the complete genome for WSMV strain Sidney 81 (GenBank accession AF057533).

Detection of WSMV. ELISA was used for virus detection. AntiWSMV antiserum was obtained from the American Type Culture Collection (Manassas, VA) and used at a working dilution of 1:3200 according to the manufacturer's instructions. Leaf samples were weighed and 0.05 to $0.10 \mathrm{~g}$ of tissue was placed in a 10-by15-cm plastic bag (Fisher Scientific, Pittsburgh). A corresponding amount of $1 \times$ PBS was added to make a 1:10 dilution (wt/vol) and the sample was macerated.

Extracted sap $(100 \mu \mathrm{l})$ was placed in each well of a 96-well BD Falcon microtiter plate (Fisher Scientific) precoated with $100 \mu \mathrm{l}$ of $1 \times$ carbonate buffer ( $0.05 \mathrm{M}$ sodium carbonate, $\mathrm{pH} 9.6)$ for $2 \mathrm{~h}$. Samples were loaded in duplicate or triplicate with $1 \times$ PBS as a background control, virus-free wheat samples maintained in the greenhouse as a negative control, and wheat inoculated with WSMV Conrad-I 2 weeks prior to the assay as a positive control. Overnight incubation at $4{ }^{\circ} \mathrm{C}$ was followed by seven cycles of rinsing with 5-s soaks with $200 \mu \mathrm{l}$ of $1 \times$ PBS with $0.5 \%$ Tween 20 (1× PBST; Agdia, Inc.) using a 96-well PW microplate washer (Tecan,
Durham, NC). WSMV antiserum diluted in ECI buffer (Agdia, Inc.) was added and the plate was incubated for $2 \mathrm{~h}$ in a sealed plastic bag at room temperature. The plate was washed as described above, and $100 \mu \mathrm{l}$ of goat anti-rabbit immunoglobulin $\mathrm{G}$ alkaline phophatase conjugate (Sigma-Aldrich, St. Louis) at a $1: 30,000$ dilution (final concentration $=5 \mu \mathrm{g} / \mathrm{ml}$ ) in ECI buffer was added to each well. After a 2-h incubation and final wash, $100 \mu \mathrm{l}$ of p-nitrophenol substrate (Agdia, Inc.) was added to the wells. The plate was incubated for $1 \mathrm{~h}$ in the dark and absorbance at $405 \mathrm{~nm}$ was measured using a microplate reader (SpectraMax Plus; Molecular Devices, Sunnywyle, CA). Absorbance values at least twice the value of the negative control were considered positive (13).

Grassy weed survey. A survey of small-grain production fields was undertaken in 2008 and 2009 to determine which weeds were potential sources of inoculum to the crop. Sampling sites were selected based on reports of virus-like symptoms from Montana county Extension Agents, samples submitted for diagnosis to the Schutter Diagnostic Lab (Montana State University, Bozeman), and visual observations from roadsides (Table 1). In 2008, the survey was performed at one location in Pondera County on 26 June (250 samples; Table 2) and at one location each in Chouteau and Pondera Counties on 15 July (525 samples; Table 2). In 2009, samples were collected from a total of 10 separate locations on 29 May and 7 and 8 July (Table 1).

To assess the overall incidence of WSMV in the symptomatic area, between 50 and 100 cereal crop leaves were sampled by walking in a zigzag pattern from the edge of the field to $5 \mathrm{~m}$ beyond the edge of the symptomatic area with two to three youngest, fully expanded leaves arbitrarily selected at each collection point. Symptoms in all fields were observed at the edge, not throughout the field. For grassy weeds, whole plants found in and adjacent to the symptomatic area were carefully collected with the seed head, when available, for later identification. Sample numbers of the grassy weeds varied based on their abundance in the field, with up 100 plants sampled per field (Tables 2 and 3). All plant materials were stored in sealed plastic bags on ice until returned to the laboratory, then subsampled for grass species identification, and frozen at $-20^{\circ} \mathrm{C}$ until processed with ELISA as described above.

Table 1. Locations sampled for Wheat streak mosaic virus (WSMV) in small-grain crops and grassy weeds in Montana in 2008 and 2009

\begin{tabular}{lcllll}
\hline Year & Site & Nearby town & County & Crop & Date \\
\hline 2008 & A & Conrad & Pondera & Winter wheat & 26 June \\
& B & Fort Benton & Chouteau & Winter wheat & 15 July \\
& C & Conrad & Pondera & Winter wheat & 15 July \\
1 & Huntley & Yellowstone & Winter wheat & 7 July \\
& 2 & Denton & Fergus & Winter wheat & 7 July \\
& 3 & Denton & Fergus & Winter wheat & 7 July \\
& 4 & Denton & Fergus & Winter wheat; spring wheat & 7 July \\
& 5 & Denton & Fergus & Winter wheat & 7 July \\
& 6 & Denton & Fergus & Winter wheat & 8 July \\
& 7 & Denton & Fergus & Barley & 8 July \\
& 8 & Ledger & Pondera & Barley & Winter wheat; spring wheat \\
\hline
\end{tabular}

Table 2. Detection of Wheat streak mosaic virus (WSMV) in crops and grassy weeds during field surveys of Montana in 2008

\begin{tabular}{|c|c|c|c|c|}
\hline \multirow[b]{2}{*}{ Common name } & \multirow[b]{2}{*}{ Scientific name } & \multicolumn{3}{|c|}{ Site (number positive/number sampled) ${ }^{\mathrm{z}}$} \\
\hline & & $\mathbf{A}$ & B & $\mathbf{C}$ \\
\hline \multicolumn{5}{|l|}{ Crop } \\
\hline Winter wheat & Triticum aestivum & $66 / 100$ & $68 / 100$ & $42 / 100$ \\
\hline \multicolumn{5}{|l|}{ Grassy weeds } \\
\hline Crested wheatgrass & Agropyron cristatum & $0 / 25$ & $0 / 25$ & $0 / 25$ \\
\hline Cheatgrass & Bromus tectorum & $0 / 25$ & $\ldots$ & $6 / 100$ \\
\hline Foxtail barley & Hordeum jubatum & $0 / 25$ & $0 / 25$ & $0 / 25$ \\
\hline Wild oat & Avena fatua & $1 / 25$ & $0 / 25$ & $0 / 50$ \\
\hline Volunteer wheat & T. aestivum & $7 / 50$ & $\ldots$ & $4 / 50$ \\
\hline
\end{tabular}

\footnotetext{
${ }^{\mathrm{z}}$ Location and date of sampling for each site is provided in Table 1. Sample numbers of each grass species varied based on their abundance in the sampled
} field. 
Relative susceptibility of grassy weeds to WSMV. To assess the degree to which grassy weed genotypes vary in susceptibility to WSMV, we collected weed seed from six Great Plains states and compared their susceptibility after mechanical and mite inoculation with WSMV strain Conrad-I. Seed of 18 grassy weed species commonly found in small-grain fields were collected from Colorado, Idaho, Montana, Nebraska, Oklahoma, and Texas (Table 4). Species were selected according to their importance as grassy weeds in cereal production fields, biological characteristics, ability to support WSMV replication and mite reproduction according to the literature $(8,49,53)$, and local prevalence information provided by collaborators from each state.

Grassy weeds were planted in $17.8-\mathrm{cm}$ pots in the planting media and growing conditions described above. At least 10 seeds of each grass species were planted approximately $2 \mathrm{~cm}$ in depth in three pots and watered as needed. To facilitate germination, the palea and lemma were removed from wild oat seed (D. Morishita, personal communication). The pots were completely randomized.

To test for differences in WSMV resistance among species or populations, the grassy weeds were mechanically inoculated with WSMV at the two- to three-leaf growth stage by hand rubbing with infectious sap as previously described. Plants were inoculated on two consecutive days to ensure a high infection rate. A pot of spring wheat Choteau was also mechanically inoculated at the twoto three-leaf growth stage at the same time as a positive control. A pot of buffer-inoculated Choteau was included in each replication as a negative control. An additional four to five pots of wheat were distributed around the experiment to check for WSMV contamination in the greenhouse. No WSMV contamination was observed for any of the experiments included in this study.

At 3 weeks post inoculation, the youngest fully expanded leaf on eight randomly selected plants was collected from each pot for virus incidence determination. The collected leaf samples were placed in individual plastic bags, macerated in a 1:10 dilution (wt/vol) of $1 \times$ PBS, and processed with ELISA as described above on duplicate plates. Each plate had two background controls (1x PBS), two negative controls (buffer-inoculated wheat, Choteau), and a positive control (Choteau, mechanically inoculated for each replication of the experiment). Inoculations were repeated five times, with one pot of 10 plants per experiment.

Additionally, we tested barley (H. vulgare 'Metcalf') and weed species susceptibility to mite-transmitted WSMV. Three grassy weed species were tested: cheatgrass, green bristlegrass, and jointed goatgrass. All seed was collected near Bozeman, MT. Plants were grown as described above, with the exception that plants were thinned to one plant per pot. Each weed species treatment was replicated 20 to 24 times. Resistance of barley to miteinoculated WSMV was tested in 36 plants. To maintain and transfer mite colonies, 5 to 10 viruliferous mites reared on spring wheat were transferred onto each weed plant by clipping a leaf segment bearing 30 to 50 mites onto the lower leaf of the recipient plant. Leaf segments were removed after $24 \mathrm{~h}$. At 3 weeks after

Table 3. Detection of Wheat streak mosaic virus (WSMV) in small-grain crops and grassy weeds in Montana during 2009

\begin{tabular}{|c|c|c|c|c|c|c|c|c|c|c|c|}
\hline \multirow{2}{*}{$\begin{array}{l}\text { Host } \\
\text { Common name }\end{array}$} & \multirow[b]{2}{*}{ Scientific name } & \multicolumn{10}{|c|}{ Sampling site (number positive/number sampled) ${ }^{\mathrm{z}}$} \\
\hline & & 1 & 2 & 3 & 4 & 5 & 6 & 7 & 8 & 9 & 10 \\
\hline \multicolumn{12}{|l|}{ Crop } \\
\hline Barley & Hordeum vulgare & $\ldots$ & $\ldots$ & $\ldots$ & $\ldots$ & $\ldots$ & $\ldots$ & $\ldots$ & $5 / 89$ & $3 / 90$ & $\ldots$ \\
\hline Spring wheat & Triticum aestivum & & $\ldots$ & $\ldots$ & $29 / 90$ & $\ldots$ & $\ldots$ & $\ldots$ & $\ldots$ & $\ldots$ & $11 / 45$ \\
\hline Winter wheat & T. aestivum & $19 / 90$ & $0 / 45$ & $1 / 91$ & $2 / 90$ & $1 / 45$ & $2 / 90$ & $32 / 90$ & $\ldots$ & $\ldots$ & $52 / 90$ \\
\hline \multicolumn{12}{|l|}{ Grassy weed } \\
\hline Crested wheatgrass & Agropyron cristatum & & $\ldots$ & $0 / 45$ & $\ldots$ & $\ldots$ & $\ldots$ & $\ldots$ & $\ldots$ & $\ldots$ & $\ldots$ \\
\hline Cheatgrass & Bromus tectorum & $20 / 90$ & $2 / 18$ & $0 / 7$ & $0 / 45$ & $\ldots$ & 9/45 & $3 / 59$ & $0 / 28$ & $0 / 16$ & $18 / 50$ \\
\hline Jointed goatgrass & Aegilops cylindricae & & $\ldots$ & $\ldots$ & $\ldots$ & $\ldots$ & $\ldots$ & $\ldots$ & $0 / 3$ & $0 / 13$ & $0 / 13$ \\
\hline Kentucky bluegrass & Poa pratensis & $3 / 20$ & $\ldots$ & $\ldots$ & $\ldots$ & $\ldots$ & $\ldots$ & $\ldots$ & $\ldots$ & $\ldots$ & $\ldots$ \\
\hline Smooth brome & B. inermis & $0 / 20$ & $\ldots$ & $\ldots$ & $\ldots$ & $\ldots$ & $\ldots$ & $\ldots$ & $\ldots$ & $\ldots$ & $\ldots$ \\
\hline Volunteer barley & H. vulgare & $\ldots$ & $\ldots$ & $\ldots$ & $\ldots$ & $\ldots$ & $\ldots$ & $\ldots$ & $\ldots$ & $3 / 25$ & $\ldots$ \\
\hline Volunteer wheat & T. aestivum & $\ldots$ & $0 / 3$ & $\ldots$ & $\ldots$ & $0 / 22$ & $\ldots$ & $\ldots$ & $2 / 21$ & $\ldots$ & $\ldots$ \\
\hline Wild rye & Elymus sp. & $0 / 5$ & $\ldots$ & $\ldots$ & $\ldots$ & $\ldots$ & $\ldots$ & $\ldots$ & $\ldots$ & $\ldots$ & $\ldots$ \\
\hline Wild oat & Avena fatua & $\ldots$ & $\ldots$ & $0 / 84$ & $0 / 2$ & $\ldots$ & $\ldots$ & $\ldots$ & $\ldots$ & $\ldots$ & $\ldots$ \\
\hline
\end{tabular}

${ }^{\mathrm{z}}$ Location and date of sampling for each site is provided in Table 1. Sample numbers of each grass species varied based on their abundance and the species' prevalence in the sampled field.

Table 4. Grassy weed species used in the Wheat streak mosaic virus host range study and their state of origin ${ }^{z}$

\begin{tabular}{lll}
\hline Common name & Scientific name & State of origin \\
\hline Barnyardgrass & Echinochloa crus-galli & Montana \\
Canada wild rye & Elymus canadensis & Texas \\
Rye brome (syn. Cheat) & Bromus secalinus & Oklahoma \\
Crested wheatgrass & Agropyron cristatum & Montana \\
Cheatgrass (syn. Downy brome) & B. tectorum & Colorado, Idaho, Montana, Nebraska, Oklahoma \\
Green bristlegrass (syn. Green foxtail) & Setaria viridis & Idaho, Montana \\
Field brome (syn. Japanese Brome) & B. arensis (syn. B. japonicus) & Texas \\
Johnsongrass & Sorghum halepense & Texas \\
Jointed goatgrass & Aegilops cylindrica & Colorado, Idaho, Montana, Nebraska \\
Quackgrass & Elymus repens & Idaho, Montana \\
Rescuegrass & B. catharticus & Oklahoma \\
Cereal rye & Secale cereale & Colorado, Oklahoma \\
Ryegrass & Lolium sp. & Oklahoma \\
Slender wheatgrass & Elymus trachycaulus & Montana \\
Smooth brome & B. inermis & Montana \\
Stinkgrass & Eragrostis cilianensis & Montana \\
Thickspike wheatgrass & Elymus lanceolatus & Montana \\
Wild oat & Avena fatua & Idaho, Montana \\
\hline
\end{tabular}

${ }^{\mathrm{z}}$ Common names were retrieved from United States Department of Agriculture NRCS Plant database. Alternate common names (synonyms) are listed from the Weed Science Society of America. 
inoculation, WSMV infection was tested as described above. Six species-specific healthy controls were used to set the ELISA cutoff values.

WCM transmission of WSMV. To evaluate the capacity of WSMV-susceptible weeds to serve as sources for transmission by WCMs to wheat, a mite colony was established from a population collected at the Arthur H. Post Agronomy Research Farm, Bozeman, MT in September 2007. Mites were identified to species with the aid of the Insect Quarantine Laboratory at Montana State University and scanning electron microscopy according to standard protocols (2). WCMs were maintained on pathogen-free spring wheat Choteau planted in a $15.2-\mathrm{cm}$ pot as previously described, with the addition of a thin layer of sand (approximately $0.7 \mathrm{~cm}$ ) on the surface, and maintained in an isolated growth chamber (16 and $8 \mathrm{~h}$ of light and darkness, respectively, at $25 \pm 0.5^{\circ} \mathrm{C}$ ). Each pot, consisting of four to five wheat plants, was individually covered by an acrylic tube $10 \mathrm{~cm}$ in diameter with three to four holes, approximately $7.0 \mathrm{~cm}$ in diameter, sealed by nylon lab pak mesh $(25 \mu \mathrm{m}$; Sefar AG, Switzerland). Once the WCM population had established, 10 to 20 mite eggs were transferred to healthy Choteau wheat at the two- to three-leaf growth stage with an eyelash brush. This process was repeated twice. The WSMV-free colony was maintained by inserting a $2.5-\mathrm{cm}$ leaf piece colonized by WCMs into a slit made on the youngest fully expanded leaf of a healthy wheat plant at growth stage Feekes 2 to 3 .

For transmission tests, mite chambers were constructed from a clear plastic 1-gal. jug (United States Plastic Corp, Lima, OH) with two side holes (approximately $5.7 \mathrm{~cm}$ in diameter) sealed with nylon lab pak mesh. Three to five $2.5-\mathrm{cm}$ leaf pieces of WSMVinoculated grassy weeds testing positive for WSMV were used as the source tissue. WSMV-infected and healthy Choteau spring wheat plants were included in each experiment as positive and negative controls, respectively. Each experiment was repeated four times. Small pieces of lightly moistened paper towels or filter papers were used to wrap the base of the source leaf pieces, which were placed in a sterile petri dish. A $2.5-\mathrm{cm}$ wheat leaf piece with at least 10 to 30 mites was placed into a slit cut into each of the grassy weed leaf pieces. The mites were allowed a 72-h acquisition access period and the presence of mites on the recipient leaflet was then confirmed under a dissecting scope. Each leaf piece of the grassy weed with WCMs was placed into a slit on single healthy Choteau wheat plant to reach a total of 10 recipient plants per source plant. Recipient wheat plants were planted in $15.2-\mathrm{cm}$ pots with the planting media described above, caged, and maintained in the greenhouse or growth chamber. Mites were allowed a 72-h inoculation access period (IAP) before an acaricide application (46) of 5 to 10 granules of Temik 15G (a.i. aldicarb; Bayer CropScience, RTP, NC) (47). The recipient wheat plant was not watered during the IAP to avoid extremely high humidity in the mite cage and molding of the mite-infested leaf pieces, which hindered mite movement to the recipient leaflet during preliminary observations. Forty-eight hours after acaricide application, recipient plants were uncaged and allowed to develop symptoms for 2 to 3 weeks. Healthy wheat plants were distributed among the experimental pots to check for mite and virus spread. Plants were tested by indirect ELISA as described above. Transmission efficiency was calculated as the number of plants that become infected out of the total number inoculated with viruliferous mites.

Statistical analysis. Analysis of variance was computed for percent incidence and relative absorbance obtained from greenhouse studies using Statistical Analysis System (SAS, ver. 9.2; SAS Institute Inc., Cary, NC). Relative absorbance for grassy weeds which showed zero incidence was excluded from the analysis. Residuals for experimental data were examined for normality by the ShapiroWilk's test (42) and homogeneity of variances by the Levene test (25). Data were log transformed as necessary, although untransformed data are presented in the tables. The SAS program Proc GLM was used for analysis over grassy weed species and, subsequently, over state of origin for the species from multiple states. Block was used as an error term within the grass species. Entry means were compared using Fisher's protected least significant difference at a significance level of $P=0.05$. When means are followed by $\pm x, x$ refers to the standard error.

\section{Results}

Field survey for WSMV. The predominant grassy weed species identified in the field survey of five Montana counties in 2008 and 2009 were jointed goatgrass, wild oat, cheatgrass, and volunteer crops. Grassy weeds were most often found on the field edge. Crops, volunteer wheat and barley, and a few cheatgrass individuals expressed virus symptoms, including chlorosis, streaking, and purpling of leaves. Symptoms were not observed on other species.

The ELISA test indicated that, in 2008, an average of $58.7 \%$ of winter wheat plants were infected with WSMV (Table 2). An average of $2.5 \%$ of grassy weeds, including volunteer crops, was infected with WSMV. Volunteer wheat had the highest incidence of WSMV infection (11.0\%), followed by cheatgrass (3.0\%) and wild oat $(1.3 \%)$. No WSMV was detected in crested wheatgrass (Agropyron cristatum (L.) Gaertn.) or foxtail barley (H. jubatum L.).

In 2009 , WSMV levels in the crops were 0.0 to $57.8 \%$, with an overall average of $15.7 \%$. Spring wheat fields $(28.3 \%$ average at two sites) had relatively more WSMV than winter wheat $(15.3 \%$ average at eight sites) or barley (4.5\% average at two sites). Volunteer crops were present at 4 of 10 sites, with an average WSMV incidence of $5.4 \%$. Cheatgrass was the most commonly identified grassy weed during the 2009 survey, being present at 9 of the 10 sites and having an average WSMV incidence of $10.5 \%$. Jointed goatgrass (average $0.0 \%$ ) and volunteer wheat (average 3.2\%) were present at 3 of 10 sites, and crested wheatgrass, Kentucky bluegrass (Poa pratensis L), smooth brome (B. inermis Leyss), and Canada wild rye (Elymus canadensis L.) were present at 1 site only (Table 3).

Susceptibility of grassy weeds to WSMV. Widely prevalent grassy weed species from six states in the Great Plains region were tested for susceptibility to a Montana strain of WSMV by mechanical inoculation (Table 4). Symptoms of WSMV varied, and were noted in only a few species. Jointed goatgrass, wild oat, and barnyardgrass had typical WSMV symptoms of yellow leaf streaking. Field brome (B. arensis L.; syn. Japanese brome, B. japonicus Thunb.), rye brome, and cheatgrass showed a mild leaf streaking. Canada wild rye, cereal rye, and ryegrass (Lolium sp.) mostly appeared asymptomatic. Green bristlegrass also appeared asymptomatic, although viral symptoms may have been masked by purpling of plant tissue which occurred regardless of whether plants were inoculated with WSMV.

Susceptibility to WSMV infection via mechanical and WCM inoculation varied among non-crop grass species but not among populations (Tables 5 and 6). Overall, winter annuals such as rye brome, field brome, jointed goatgrass, and cereal rye were more susceptible to WSMV than summer annuals or perennials, as measured by the incidence of infection. Jointed goatgrass had the highest infection rate $(80.4 \%)$ among the species tested, followed by wild oat $(53.9 \%)$ and rye brome $(52.1 \%)$. Grassy weeds with moderately high (30 to $50 \%$ ) incidence of WSMV following mechanical inoculation included cheatgrass, field brome, and cereal rye. Two summer annuals, barnyardgrass and green bristlegrass, had a relatively low $(<30 \%)$ incidence of WSMV infection. All perennial grasses were infrequently infected $(<20 \%)$, including Canada wild rye, quackgrass (E. repens (L.) Gould), and ryegrass. Crested wheatgrass (A. cristatum (L.) Gaertn.), johnsongrass (Sorghum halepense (L.) Pers.), smooth brome, stinkgrass (Eragrostis cilianensis (All.) Vign. ex Janchen), rescuegrass (B. catharticus Vahl), slender wheatgrass (Elymus trachycaulus (L.) Gould ex Shinners), and thickspike wheatgrass (E. lanceolatus (Scribn. \& J. G. Sm.) Gould) were not susceptible to WSMV. Cheatgrass, green bristlegrass, jointed goatgrass, quackgrass, cereal rye, and wild oat genotypes from multiple states were tested, and no significant differences in incidence were observed based on state of origin (Table 6). 
We tested mite inoculation of several grass species to evaluate the efficiency of mite versus mechanical inoculation. Barley, which in field trials has been resistant to mechanical inoculations with WSMV (mean incidence $=0.7 \pm 1.2 \%$ ), was highly susceptible to mite inoculation (88\%; Fig. 1). Green bristlegrass susceptibility was higher to mite inoculation than mechanical (63.6 and $28.1 \%$, respectively; Table 5). The susceptibility of cheatgrass (mite: 20.0\%, mechanical: $32.6 \%$ ) and jointed goatgrass (mite: $95.8 \%$, mechanical: $80.9 \%$ ) was similar regardless of the mechanism of transmission.

Transmission of WSMV from grassy weeds to wheat. Transmission of WSMV from grassy weeds to cereal crops is an important step in evaluating their role as a source of inoculum. Grass species varied in their capacity to serve as transmission hosts for WSMV $(P<0.01$; Table 7$)$. The highest transmission efficiency was observed from spring wheat $(46.7 \%)$. Rye brome, cheatgrass, field brome, and jointed goatgrass had approximately $20.0 \%$ transmission efficiency. Barnyardgrass, Canada wild rye, green bristlegrass, cereal rye, and ryegrass were poor virus sources, with less than $10.0 \%$ transmission efficiency. No transmission was observed from crested wheatgrass, quackgrass, smooth brome, or wild oat.

\section{Discussion}

To our knowledge, this study represents the first quantification of the susceptibility of alternative hosts to WSMV from a large geographic area and the first demonstration of WCM transmission of WSMV from grassy weeds to wheat. We also demonstrated that estimates of host susceptibility to WSMV can vary based on whether the host is inoculated mechanically or by the WCM vector.

Our results indicated that, as a general rule, winter annual grassy species from across the Great Plains had more species susceptible to WSMV, estimated as incidence, than summer annuals or perennials. In our field survey of Montana, winter annuals were more frequently identified and denser in population than summer annuals. This observation fits with crop management in the surveyed area, which produces primarily winter wheat (United States Department of Agriculture National Agricultural Statistics Service).

Wild oat, a summer annual commonly infecting spring wheat fields, was as susceptible to WSMV as spring wheat. However, in accordance with a previous study (15), our results indicate that wild oat does not support WCMs and was found infected at very low numbers $(<1 \%)$ in field surveys. In addition, although WCM populations in Australia have been reported to reproduce on wild oat $(12,15)$, in our study, WCMs were not able to transmit WSMV from wild oat to wheat. It is unknown whether this adaptation to wild oat originated in Australia or North America, or whether wild oat in Australia can serve as a viral source. Siriwetwiwat (46) observed local adaptation of mite populations to local wheat varieties. It is possible that mite populations are also adapted to grass species. Indeed, observations in our laboratory support this possibility, because many mite populations collected from wild grasses were not able to reproduce when placed directly on wheat. The adaptation of WCM populations to particular hosts and also their capacity to transmit virus species and strains (38) could influence viral epidemics.

Winter annual grasses germinating in the fall may provide an important overwintering reservoir for the virus and mite vector in

Table 6. Difference in incidence among grassy weed species from multiple Great Plains states to a Montana strain of Wheat streak mosaic virus $(\mathrm{WSMV})^{\mathrm{z}}$

\begin{tabular}{lllrr}
\hline Common name & Scientific name & $\begin{array}{c}\text { State } \\
\text { of origin }\end{array}$ & $\begin{array}{c}\text { Inc. } \\
(\boldsymbol{\%})\end{array}$ & \multicolumn{1}{c}{ SE } \\
\hline Cheatgrass & Bromus tectorum & Colorado & 32.5 & 11.5 \\
& & Idaho & 32.0 & 17.8 \\
& & Montana & 27.6 & 10.2 \\
& & Nebraska & 45.3 & 22.3 \\
Green bristlegrass & \multirow{2}{*}{ Setaria viridis } & Oklahoma & 25.4 & 4.6 \\
& & Idaho & 33.3 & 18.3 \\
Jointed goatgrass & \multirow{2}{*}{ Aegilops cylindrica } & Montana & 22.9 & 11.4 \\
& & Colorado & 85.6 & 4.6 \\
& & Idaho & 81.8 & 4.1 \\
Cereal rye & \multirow{2}{*}{ Secale cereale } & Nebrana & 65.7 & 13.2 \\
Quackgrass & Colorado & 90.5 & 4.7 \\
& \multirow{2}{*}{ Elymus repens } & Oklahoma & 34.6 & 8.9 \\
& & Idaho & 16.7 & 9.6 \\
& \multirow{2}{*}{ Avena fatua } & Montana & 9.4 & 4.4 \\
& & Idaho & 65.0 & 11.6 \\
& & Montana & 42.7 & 11.7 \\
\hline
\end{tabular}

${ }^{\mathrm{z}}$ All grass species were tested 3 weeks after mechanical inoculation with WSMV isolate Conrad-I for incidence (Inc.). There were no differences among incidence based on state of origin $(P>0.05)$. Data were log transformed (the untransformed means are presented) and analyzed by analysis of variance with experiments designated as a random factor. $\mathrm{SE}=$ standard error.

Table 5. Relative susceptibility of grassy weed species from six Great Plains states to Wheat streak mosaic virus (WSMV) as measured by mean incidence ${ }^{\mathrm{z}}$

\begin{tabular}{|c|c|c|c|c|}
\hline Common name & Scientific name & Growth cycle & Inc. $(\%)$ & SE \\
\hline Barnyardgrass & Echinochloa crus-galli & Summer annual & $26.0 \mathrm{de}$ & 13.2 \\
\hline Canada wild rye & Elymus canadensis & Perennial & $4.8 \mathrm{f}$ & 2.8 \\
\hline Rye brome (Cheat) & Bromus secalinus & Winter annual & $52.1 \mathrm{~b}$ & 15.1 \\
\hline Crested wheatgrass & Agropyron cristatum & Perennial & $0.0 \mathrm{f}$ & 0.0 \\
\hline Cheatgrass (downy brome) & B. tectorum & Winter annual & $32.6 \mathrm{~cd}$ & 6.1 \\
\hline Green bristlegrass & Setaria viridis & Summer annual & $28.1 \mathrm{de}$ & 10.3 \\
\hline Field brome & B. arvensis & Winter annual & $42.4 \mathrm{bcd}$ & 11.7 \\
\hline Johnsongrass & Sorghum halapense & Perennial & $0.0 \mathrm{f}$ & 0.0 \\
\hline Jointed goatgrass & Aegilops cyrindlica & Winter annual & $80.9 \mathrm{a}$ & 4.1 \\
\hline Rescuegrass & B. catharticus & Winter annual & $0.0 \mathrm{f}$ & 0.0 \\
\hline Cereal rye & Secale cereale & Winter annual & $46.2 \mathrm{bc}$ & 8.7 \\
\hline Ryegrass & Lolium sp. & & $9.9 \mathrm{ef}$ & 2.6 \\
\hline Slender wheatgrass & Elymus trachycaulus & Perennial & $0.0 \mathrm{f}$ & 0.0 \\
\hline Smooth brome & B. inermis & Perennial & $0.0 \mathrm{f}$ & 0.0 \\
\hline Stinkgrass & Eragrostis cilianensis & Summer annual & $0.0 \mathrm{f}$ & 0.0 \\
\hline Thickspike wheatgrass & Elymus lanceolatus & Perennial & $0.0 \mathrm{f}$ & 0.0 \\
\hline Quackgrass & Elymus repens & Perennial & $12.7 \mathrm{ef}$ & 4.7 \\
\hline Wild oat & Avena fatua & Summer annual & $53.9 \mathrm{~b}$ & 8.6 \\
\hline Wheat (spring wheat) & Triticum aestivum (negative control) & $\ldots$ & $0.0 \mathrm{f}$ & 0.0 \\
\hline
\end{tabular}

${ }^{\mathrm{z}}$ All grass species were tested by enzyme-linked immunosorbent assay 3 weeks after mechanical inoculation of WSMV Montana isolate Conrad-I. Percent incidence (Inc.) was determined from screening eight plants per pot. Inoculated 'Choteau' exhibited 100\% incidence. Data were log transformed (the untransformed means are presented) and analyzed by analysis of variance. Means comparisons were performed using a Fisher's protected least significant difference designating replications as a random factor. Means followed by the same letter within each column are not significantly different at $P=0.05$. SE $=$ standard error. 


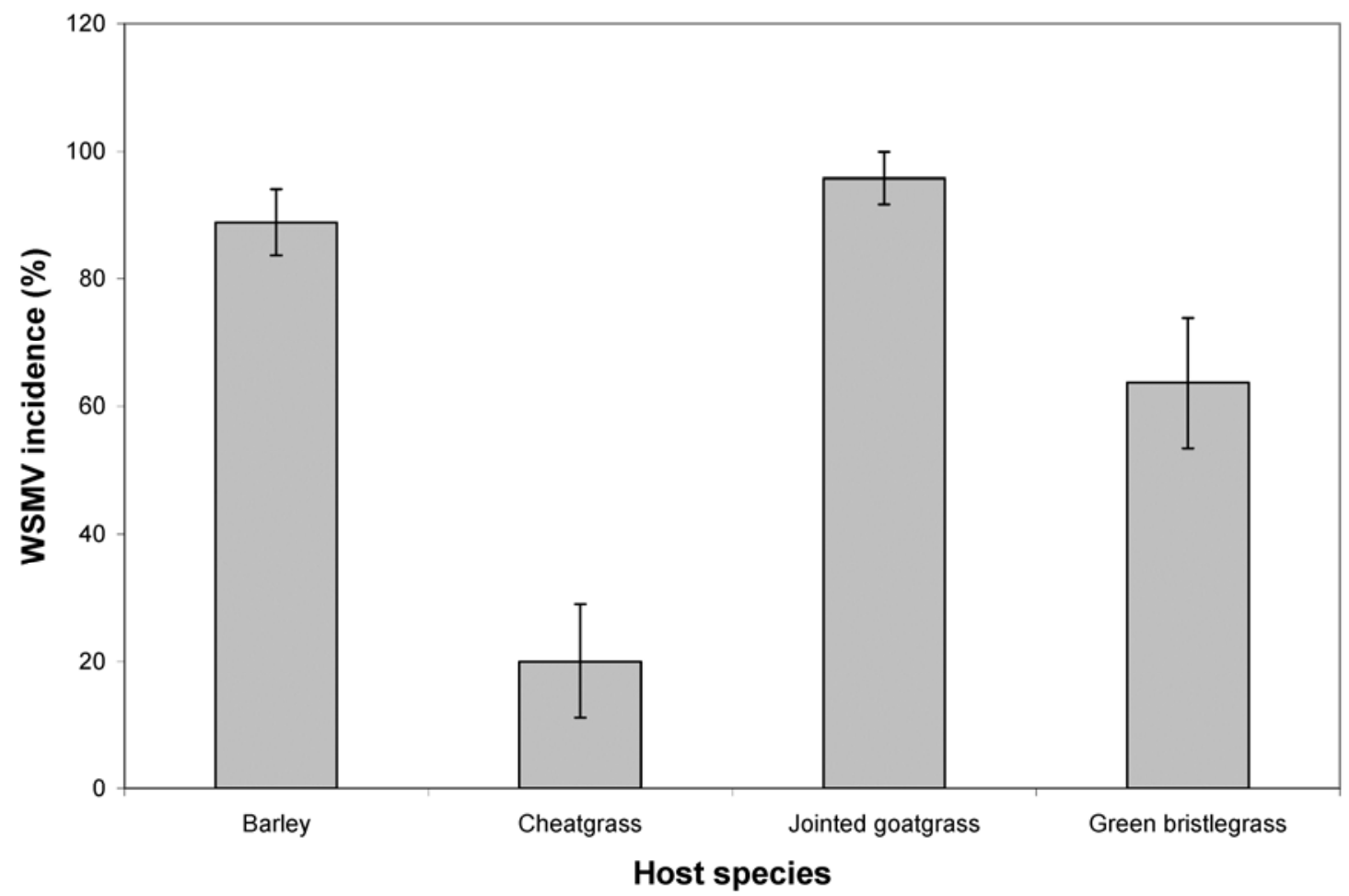

Fig. 1. Transmission efficiency of Wheat streak mosaic virus (WSMV) from spring wheat to grassy weed species with wheat curl mites, Aceria toshichella. Error bar represents standard error.

northern climates. In addition, early maturity compared with the cereal crop may encourage movement of the mite off a winter annual grass during the tillering or early reproductive stages of winter crops $(22,52)$. Winter annual grasses often emerge before winter wheat and are controlled prior to planting, usually by using a herbicide, often accompanied by planting winter wheat on the same day or shortly thereafter. This management approach could provide a green bridge for virus movement into the crop because herbicides can increase WCM dispersal $(22,52)$. This movement of the mite to new host plants, including summer annual grasses and spring wheat, which would mature later in the season, could increase the mite population density for infection of winter annual grasses in the fall. In contrast, summer annual grasses do not provide an overwintering reservoir of virus or mite and are less susceptible to WSMV. The exception to that rule is wild oat, a summer annual that is susceptible to WSMV. However, it is not susceptible to the WCM and did not serve as a viral source in our transmission studies. Other studies have favored summer annual grasses such as barnyardgrass and green bristlegrass as important sources of WSMV (13). However, it is unclear what the source of infection in that study was and whether the plant community could be a significant source of viral inoculum to the crop. It is likely that the importance of grass species as a source of WSMV and the WCM varies according to geographic region (44) and cropping practices. From the results of our study, we conclude that, at least in the northern Great Plains, winter annual weeds, especially jointed goatgrass, as well as volunteer wheat and barley appear to be the best reservoirs for vector and virus. Components contributing to the importance of the inoculum source include the cropping system, population, composition, and density of plant species, as well as the temporal dynamics of these species (27).

In addition to testing grass species per se, we also investigated whether grass species from different states in the Great Plains that varied in the frequency of WSMV epidemics would also vary in their susceptibility to WSMV. We found that many grassy weeds prevalent in the Great Plains region are susceptible to WSMV and can serve as sources of inoculum for transmission by the WCM. There was very little variation in the susceptibility to one strain of WSMV based on the geographic origin of the plant, indicating that variation in regional weed biotype is not a major contributor to epidemic frequency. However, regional variations in WSMV strains and mite biotypes may contribute to epidemic frequency. A study by McNeil et al. (29) indicated that genetic variability of WSMV is high within a single crop field, and preliminary greenhouse and field testing indicates that the origin of WSMV affects the susceptibility of the wheat variety (M. Burrows, personal observation). For example, winter wheat cultivars from Texas are more susceptible to a strain of WSMV collected from Texas than the Conrad-I strain from Montana (data not shown). This indicates potential regional variability of viral strains. Also, weed species susceptibility can differ based on the method by which the susceptibility was tested. Mainly, WCMs appear to be much more efficient vectors of WSMV to species such as green bristlegrass, whereas mite and mechanical transmission efficiency to cheatgrass and jointed goatgrass are similar. It has been assumed in the literature that plant resistance to WSMV can be accurately measured using mechanical transmission. However, the differences we observed in this study suggest that this may not be true and needs to be tested.

In addition to viral strains, the genetic variation in mites and their host adaptation affect transmission efficiency and mite reproduction. Siriwetwiwat (46) found that WCM biotypes were as variable on a single head of wheat as in an entire field, and Seifers (38) and Coutts (15) found regional variation in the transmission of WMoV and WSMV from different sources of WCM. Our research (data not shown) and Siriwetwiwat (46) have found that WCMs reproduce more quickly on plants infected with WSMV collected in the same geographic area as the WCMs, indicating that the capacity of WCMs to reproduce is reduced on a host to which it is not adapted $(16,32)$. This was seen in our laboratory, where WCMs collected from many grass species would not feed and reproduce on wheat, and with other eriophyid mites such as the cereal rust mite (Abacarus hystrix Nalepa; 48). Taken together, these results suggest that regional and host adaptation of virus and mite biotypes are likely critical to epidemic development.

Cultural practices are important to controlling WSMV epidemics. The high prevalence of continuous wheat cropping in southern states (33) favors epidemics. In northern climates, the green bridge 
Table 7. Susceptibility to the wheat curl mite (WCM) and the Wheat streak mosaic virus (WSMV) and comparison of WSMV transmissibility by WCMs from grassy weeds to spring wheat

\begin{tabular}{|c|c|c|c|c|c|}
\hline \multirow[b]{2}{*}{ Common name } & \multirow[b]{2}{*}{ Scientific name } & \multicolumn{2}{|c|}{ Susceptibility $^{\mathrm{y}}$} & \multicolumn{2}{|c|}{ Transmission $^{\mathrm{z}}$} \\
\hline & & WCM & WSMV & Inc. $(\%)$ & SE \\
\hline Jointed goatgrass & Aegilops cylindricae & $\mathrm{S}$ & $\mathrm{S}$ & $22.5 \mathrm{bc}$ & 7.5 \\
\hline Quackgrass & Elymus repens & $\mathrm{S}$ & I & $0.0 \mathrm{~d}$ & 0.0 \\
\hline Wild oat & Avena fatua & I & $\mathrm{S}$ & $0.0 \mathrm{~d}$ & 0.0 \\
\hline Field brome & Bromus arvensis & $\mathrm{S}$ & $\mathrm{S}$ & $23.3 \mathrm{~b}$ & 6.7 \\
\hline Rye brome & B. secalinus & $\mathrm{S}$ & $\mathrm{S}$ & $23.3 \mathrm{~b}$ & 3.3 \\
\hline Cheatgrass & B. tectorum & $\mathrm{S}$ & $\mathrm{S}$ & $20.0 \mathrm{bc}$ & 4.1 \\
\hline Barnyardgrass & Echinochloa crus-galli & $\mathrm{S}$ & $\mathrm{S}$ & $5.0 \mathrm{~d}$ & 2.9 \\
\hline Canada wild rye & Elymus canadensis & $\mathrm{S}$ & $\mathrm{S}$ & $6.7 \mathrm{~d}$ & 3.3 \\
\hline Ryegrass & Lolium sp. & $\mathrm{S}$ & $\mathrm{S}$ & $6.7 \mathrm{~d}$ & 3.3 \\
\hline Cereal rye & Secale cereale & $\mathrm{S}$ & $\mathrm{S}$ & $10.0 \mathrm{~cd}$ & 0.0 \\
\hline Green bristlegrass & Setaria viridis & $\mathrm{S}$ & $\mathrm{S}$ & $10.0 \mathrm{~cd}$ & 5.8 \\
\hline Wheat (spring) & Triticum aestivum (positive control) & $\mathrm{S}$ & $\mathrm{S}$ & $46.7 \mathrm{a}$ & 8.8 \\
\hline Wheat (spring) & T. aestivum (negative control) & $\mathrm{S}$ & $\mathrm{S}$ & 0.0 & 0.0 \\
\hline
\end{tabular}

y Data for WCM susceptibility are from Somsen and Sill (49), Townsend and Johnson (53), and Brey et al. (8). S = susceptible and I = immune.

${ }^{\mathrm{z}}$ WSMV source plants were enzyme-linked immunosorbent assay (ELISA)-positive plants from relative susceptibility experiments (Tables 5 and 6). Wheat controls were spring wheat 'Choteau'. Percent incidence (Inc.) was calculated as the number of plants ELISA positive for WSMV per total number of plants infested with viruliferous mites. This experiment was performed four times and analyzed by analysis of variance, where replications were designated as a random factor. Means followed by the same letter are not significantly different at $P=0.05$ based on Fisher's protected least significant difference. SE $=$ standard error.

is increasingly favored by early planting of winter wheat to increase yields and to ensure adequate growth before winter (28), incorporation of "stay-green" traits in spring wheat varieties (5), and abundant volunteer crop due to lodging caused by hail and insect pests such as the wheat stem sawfly (21). In addition, an increase in the density of grassy weeds has been facilitated by widespread use of semidwarf crop varieties, late weed control, reduced or no tillage, adoption of non-till practices, and application of broadcast nitrogen fertilizer $(3,4,17,34)$. In addition, changes in climate $(3,20,23)$ and invasive species composition (27) may alter viral epidemiology in future years. These factors, and the discovery of WMoV and TriMV throughout the Great Plains $(10,11)$, may increase the importance of cereal viruses in the future.

Susceptibility of grassy weeds is one of the contributing factors for understanding WSMV epidemiology but the impact of grassy weeds on the spread and persistence of virus and vector depends upon more complex interactions than those tested here. Future studies should evaluate the ability of the host species to support vector populations through fallow periods, persistence of infection in perennial hosts, and relationships between titer level and rates of vector acquisition of virus. In addition, these studies must consider changes in the local distribution of the grassy weeds as a function of management practices (35) and WCM movements in the field and the impact of landscape and geographic variables to predict the frequency and severity of local WSMV epidemics.

\section{Acknowledgments}

This work was supported with funding from the Montana Wheat and Barley Committee and the United States Department of Agriculture Crops at Risk Program. We thank C. Seibert for plant identification from field surveys; J. Littlefield and R. Ochoa for assistance with mite identification; D. Morishita for insight into Avena fatua germination; C. Henne, B. Hunger, C. Rush., S. Wegulo, and $\mathrm{J}$. Windes for collecting grassy weed seed in their state; Montana growers and extension agents for assistance with field surveys; and K. Baker and S. Terrill for technical assistance.

\section{Literature Cited}

1. Altschul, S. F., Madden, T. L., Schaffer, A. A., Zhang, J. H., Zhang, Z., Miller, W., and Lipman, D. J. 1997. Gapped BLAST and PSI-BLAST: a new generation of protein database search programs. Nucleic Acids Res. 25:3389-3402.

2. Amrine, J. W., and Mason, D. C. M. 1996. Preparation, mounting and descriptive study of Eriophyoid mites. Pages 383-396 in: Eriophyoid MitesTheir Biology, Natural Enemies and Control. E. E. Lindquist, M. W. Sabelis, and J. Bruin, eds. Elsevier Science.

3. Anderson, P. K., Cunningham, A. A., Patel, N. G., Morales, F. J., Epstein, P. R., and Daszak, P. 2004. Emerging infectious diseases of plants: pathogen pollution, climate change and agrotechnology drivers. Trends Ecol. Evol. 19:535-544.

4. Blackshaw, R. E. 1994. Rotation effects on downy brome (Bromus tecto- rum) in winter wheat (Triticum aestivum). Weed Technol. 8:728-732.

5. Blake, N. K., Lanning, S. P., Martin, J. M., Sherman, J. D., and Talbert, L. E. 2007. Relationship of flag leaf characteristics to economically important traits in two spring wheat crosses. Crop Sci. 47:491-496.

6. Bockus, W., Bowden, R., Hunger, R., Morrill, W., Murray, T., and Smiley, R., eds. 2010. Compendium of Wheat Diseases and Pests, 3rd ed. American Phytopathological Society, St. Paul, MN.

7. Bottacin, A., and Nassuth, A. 1990. Evaluation of Ontario-grown cereals for susceptibility to wheat streak mosaic virus. Can. J. Plant Pathol. 12:267272.

8. Brey, C. W., Johnson, G. D., and Blodgett, S. L. 1998. Survey of Montana grasses for wheat curl mite (Acari: Eriophyidae), the vector of Wheat streak mosaic virus. J. Agric. Entomol. 15:173-181.

9. Burrows, M., Ito, D., and Grey, W. 2009. Cereal viruses of importance in Montana. Mont. State Univ. Ext. Publ. MT200911AG. Bozeman.

10. Burrows, M., Rush, C., and Franc, G. 2009. Occurrence of viruses in wheat in the Great Plains region, 2008. Plant Health Progress. Online publication. doi:10.1094/PHP-2009-0706-01-RS

11. Burrows, M., and Stack, J. 2009. Great Plains Diagnostic Network Regional Wheat Virus Survey: Collaboration, Communication, Research and Extension Outcomes. NPDN National Meeting, Miami, FL.

12. Carew, M., Schiffer, M., Umina, P., Weeks, A., and Hoffmann, A. 2009. Molecular markers indicate that the wheat curl mite, Aceria tosichella Keifer, may represent a species complex in Australia. B. Entomol. Res. 99:479-486.

13. Christian, M. L., and Willis, W. G. 1993. Survival of wheat streak mosaic virus in grass hosts in Kansas from wheat harvest to fall wheat emergence. Plant Dis. 77:239-242.

14. Connin, R. V. 1956. The host range of the wheat curl mite, vector of wheat streak mosaic. J. Econ. Entomol. 49:1-4.

15. Coutts, B. A., Strickland, G. R., Kehoe, M. A., Severtson, D. L., and Jones, R. A. C. 2008. The epidemiology of Wheat streak mosaic virus in Australia: case histories, gradients, mite vectors, and alternative hosts. Aust. J. Agric. Res. 59:844-853.

16. Del Rosario, M. S., and Sill, W. H. 1958. A method of rearing large colonies of an eriophyid mite, Aceria tulipae (Keifer), in pure culture from single eggs or adults. J. Econ. Entomol. 51:303-306.

17. Derksen, D. A., Anderson, R. E., Blackshaw, R. E., and Maxwell, B. 2002. Weed dynamics and management strategies for cropping systems in the Northern Great Plains. Agron. J. 94:174-185.

18. Graybosch, R. A., Peterson, C. J., Baenziger, P. S., Baltensperger, D. D., Nelson, L. A., Jin, Y., Kolmer, J., Seabourn, B., French, R., Hein, G., Martin, T. J., Beecher, B., Schwarzacher, T., and Heslop-Harrison, P. 2009. Registration of 'Mace' hard red winter wheat. J. Plant Regist. 3:51-56.

19. Hall, J. S., French, R., Morris, T. J., and Stenger, D. C. 2001. Structure and temporal dynamics of populations within Wheat streak mosaic virus isolates. J. Virol. 75:10231-10243.

20. Harvell, C. D., Mitchell, C. E., Ward, J. R., Altizer, S., Dobson, A. P., Ostfeld, R. S., and Samuel, M. D. 2002. Ecology — climate warming and disease risks for terrestrial and marine biota. Science 296:2158-2162.

21. Hatfield, P. G., Blodgett, S. L., Spezzano, T. M., Goosey, H. B., Lenssen, A. W., Kott, R. W., and Marlow, C. B. 2007. Incorporating sheep into dryland grain production systems I. Impact on over-wintering larva populations of wheat stem sawfly, Cephus cinctus Norton (Hymenoptera: Cephidae). Small Ruminant Res. 67:209-215. 
22. Jiang, W., Garrett, K. A., Peterson, D. E., Harvey, T. L., Bowden, R. L., and Fang, L. 2005. The window of risk for emigration of Wheat streak mosaic virus varies with host eradication method. Plant Dis. 89:853-858.

23. Jones, R. A. C. 2009. Plant virus emergence and evolution: origins, new encounter scenarios, factors driving emergence, effects of changing world conditions, and prospects for control. Virus Res. 141:113-130.

24. Langham, M., Doxtader, D. C., Haley, S. D., Kalsbeck, S., Little, R. S., and Ibrahim, A. M. 2001. Yield and growth reductions in winter wheat infected with Wheat streak mosaic virus. (Abstr.) Phytopathology 91:S52.

25. Levene, H. 1960. Robust tests for equality of variances. Pages 278-292 in: Contributions to Probability and Statistics. I. Olkin, ed. Stanford University Press, Palo Alto, CA.

26. Mahmood, T., Hein, G. L., and Jensen, S. G. 1998. Mixed infection of hard red winter wheat with High Plains virus and Wheat streak mosaic virus from wheat curl mites in Nebraska. Plant Dis. 82:311-315.

27. Malstrom, C. M., McCullough, A. J., Johnson, H. A., Newton, L. A., and Borer, E. T. 2005. Invasive annual grasses indirectly increase virus incidence in California native perennial bunchgrasses. Oecologia 145:153-164.

28. Matz, S. A. 1991. The Chemistry and Technology of Cereals as Food and Feed, 2nd ed. Van Nostrand Reinhold/AVI, New York.

29. McNeil, J. E., French, R., Hein, G. L., Baenziger, P. S., and Eskridge, K. M. 1996. Characterization of genetic variability among natural populations of Wheat streak mosaic virus. Phytopathology 86:1222-1227.

30. Montana, J. R., Hunger, R. M., and Sherwood, J. L. 1996. Serological characterization of Wheat streak mosaic virus isolates. Plant Dis. 80:1239-1244.

31. Myslik, J. T., and Nassuth, A. 2001. Rapid detection of viruses, transgenes, and mRNAs in small plant leaf samples. Plant Mol. Biol. Rep. 19:329-340.

32. Orlob, G. B. 1966. Epidemiology of wheat streak mosaic in South Dakota 1962-1966. Host range studies. Plant Dis. Rep. 66:406-414.

33. Padgitt, M., Newton, D., Penn, R., and Sandretto, C. 2000. Production Practices for Major Crops in U.S. Agriculture, 1990-97. Economic Research Service, U. S. Dep. Agric.

34. Pollnac, F. W., Maxwell, B. D., and Menalled, F. D. 2009. Using speciesarea curves to examine weed communities in organic and conventional spring wheat systems. Weed Sci. 57:241-247.

35. Pollnac, F. W., Rew, L. J., Maxwell, B. D., and Menalled, F. D. 2008. Spatial patterns, species richness and cover in weed communities of organic and conventional no-tillage spring wheat systems. Weed Res. 48:398-407.

36. Rabenstein, F., Seifers, D. L., Schubert, J., French, R., and Stenger, D. C. 2002. Phylogenetic relationships, strain diversity and biogeography of tritimoviruses. J. Gen. Virol. 83:895-906.

37. Seifers, D. L., Harvey, T. L., Kofoid, K. D., and Stegmeier, W. D. 1996. Natural infection of pearl millet and sorghum by Wheat streak mosaic virus in Kansas. Plant Dis. 80:179-185.

38. Seifers, D. L., Harvey, T. L., Louie, R., Gordon, D. T., and Martin, T. J. 2002. Differential transmission of isolates of the High Plains virus by different sources of wheat curl mites. Plant Dis. 86:138-142.

39. Seifers, D. L., Harvey, T. L., Martin, T. J., and Jensen, S. G. 1997 Identification of the wheat curl mite as the vector of the High Plains virus of corn and wheat. Plant Dis. 81:1161-1166.

40. Seifers, D. L., Harvey, T. L., Martin, T. J., and Jensen, S. G. 1998. Partial host range of the High Plains virus of corn and wheat. Plant Dis. 82:875879 .

41. Seifers, D. L., Martin, T. J., and Fellers, J. P. 2010. An experimental host range for Triticum mosaic virus. Plant Dis. 94:1125-1131.

42. Shapiro, S. S., and Wilk, M. B. 1965. An analysis of variance test for normality (complete samples). Biometrika 52:591-611.

43. Sharp, G. L., Martin, J. M., Lanning, S. P., Blake, N. K., Brey, C. W., Sivamani, E., Qu, R., and Talbert, L. E. 2002. Field evaluation of transgenic and classical sources of Wheat streak mosaic virus resistance. Crop Sci. 42:105-110.

44. Sill, W. H., and Agusiobo, P. C. 1955. Host range studies of the wheat streak mosaic virus. Plant Dis. Rep. 39:633-642.

45. Sill, W. H., and Connin, R. V. 1953. Summary of the known host range of the wheat streak-mosaic virus. Trans. Kans. Acad. Sci. 56:411-417.

46. Siriwetwiwat, B. 2006. Interaction between the wheat curl mite, Aceria tosichella Keifer (Eriophyidae), and the Wheat streak mosaic virus and distribution of wheat curl mite biotypes in the field. Thesis, UMI Number 3237062, University of Nebraska. Lincoln.

47. Skare, J. M., Wijkamp, I., Rezende, J., Michels, G., Rush, C., Scholthof, K. B. G., and Scholthof, H. B. 2003. Colony establishment and maintenance of the eriophyid wheat curl mite Aceria tosichella for controlled transmission studies on a new virus-like pathogen. J. Virol. Methods 108:133-137.

48. Skoracka, A., and Kuczynski, L. 2006. Is the cereal rust mite, Abacarus hystrix really a generalist? Testing colonization performance on novel hosts. Exp. Appl. Acarol. 38:1-13.

49. Somsen, H. W., and Sill, W. H. 1970. The wheat curl mite, Aceria tulipae Keifer, in relation to epidemiology and control of wheat streak mosaic. Kans. Agric. Exp. Stn. Res. Publ. 162.

50. Stenger, D., Young, B., Qu, F., Morris, T., and French, R. 2007. Wheat streak mosaic virus $\mathrm{P} 1$, not $\mathrm{HC}$-Pro, facilitates disease synergism and suppression of post-transcriptional gene silencing. (Abstr.) Phytopathology 97:S111.

51. Stenger, D. C., and French, R. 2009. Wheat streak mosaic virus genotypes introduced to Argentina are closely related to isolates from the American Pacific Northwest and Australia. Arch. Virol. 154:331-336.

52. Thomas, J. A., and Hein, G. L. 2003. Influence of volunteer wheat plant condition on movement of the wheat curl mite, Aceria tosichella, in winter wheat. Exp. Appl. Acarol. 31:253-268.

53. Townsend, L., Johnson, D., and Hershman, D. 1996. Wheat streak mosaic virus and the wheat curl mite. In: Entfact-117. University of Kentucky College of Agriculture, Lexington. 